\title{
Acute Lymphoblastic Leukemia: An Unusual cause of Nephromegaly in Infancy
}

\begin{abstract}
Sir,
We present here an infant who had acute lymphoblastic leukemia with massively enlarged kidneys due to leukemic infiltrates. A 7-month-old girl child presented with complaints of low grade fever and coryza for 6 days. The mother noticed angular deviation of mouth and tongue to right side for the past 4 days and decreased movements of right upper limb for same duration. On examination, the child had pallor and few petechie over the trunk. The vitals were HR $122 / \mathrm{min}$, pulses well palpable, RR 48/min; blood pressure was 134/94 mm Hg. Her anthropometry was: weight $6.6 \mathrm{Kg}$ (10th centile), length $65 \mathrm{~cm}\left(25^{\text {th }}\right.$ centile), and head circumference was $41.5 \mathrm{~cm}\left(25^{\text {th }}\right.$ centile). Central nervous system examination revealed normal sensorium. There was left facial lower motor neuron palsy, right hypoglossal palsy and right sided hemiparesis (upper motor neuron type). There were no meningeal or cerebellar signs. She had a soft hepatomegaly $(2.5 \mathrm{~cm}$ below costal margin) and splenomegaly ( $6 \mathrm{~cm}$ below costal margins). Bilateral kidneys were palpable and occupied most of the abdomen, their surface was smooth.
\end{abstract}

The mother had undergone ultrasonography during the antenatal period and no abnormality of fetal kidneys was reported. Initial investigations revealed hemoglobin $5.8 \mathrm{~g} \%$, TLC $7500 / \mu \mathrm{l}$, polymorphs 35 , lymphocytes 65 and Platelet count of $26 \times 10^{\circ} / \mathrm{L}$. The peripheral smear had normocytic normochromic to mildly hypochromic red blood cells, platelets were diminished and 3\% blasts were present. The biochemistry showed blood urea $45 \mathrm{mg} / \mathrm{dL}$, serum creatinine $0.8 \mathrm{mg} / \mathrm{dL}$, serum ALT $24 \mathrm{IU} / \mathrm{L}$, AST 25 $\mathrm{IU} / \mathrm{L}$. albumin $4.1 \mathrm{gm} / \mathrm{dL}$, SAP $240 \mathrm{IU} / \mathrm{L}$. The serum sodium was $133 \mathrm{mEq} / \mathrm{L}, \mathrm{K} 4.0 \mathrm{mEq} / \mathrm{L}$, calcium $8.2 \mathrm{mg} /$ $\mathrm{dL}$, and phosphates $5.4 \mathrm{mg} / \mathrm{dL}$. A venous blood gas had a pH of 7.35 , bicarbonate $21 \mathrm{mEq} / \mathrm{L}$, base excess $-5 \mathrm{mEq} /$ L. A lumbar puncture examination done showed 80 cells, polymorphs 45 and lymphocytes 25 and presence of abnormal cells; CSF sugar was $87 \mathrm{mg} / \mathrm{dL}$ and protein 62 $\mathrm{mg} / \mathrm{dL}$. Glomerular filtration rate as calculated by the Schwartz method was $45 \mathrm{ml} / \mathrm{min} / 1.73 \mathrm{~m}^{2}$.

An ultrasonogram of the abdomen revealed liver of normal size and echotexture. The spleen was enlarged 9.2 $\mathrm{cm}$, right kidney $(10.7 X 5.0 \mathrm{~cm})$; left kidney $(10.2 \times 5.5 \mathrm{~cm})$, bilateral grossly enlarged kidneys with smooth outline extending from epigastrium to pelvic inlet compressing midline retroperitoneal vessels. Multiple dilated tubular structures were seen in cortex and medulla. A computed tomography of the abdomen showed enlarged smooth kidneys with no cystic dilatation with maintained corticomedullary differentiation. An MRI of the brain was suggestive of generalized brain atrophy. A bone marrow aspirate showed presence of $21 \%$ lymphobalsts (PAS \& myeloperoxidase negative blasts) in the marrow. A diagnosis of acute lymphoblastic leukemia with renal and CNS infiltrations was made. A renal biopsy was not done in view of persistent thrombocytopenia.

The child was started on chemotherapy for standard risk: ALL (prednisolone, L-asparginase and vincristine), intrathecal methotrexate, hydrocortisone and cytarabine. After the first cycle of chemotherapy the liver, spleen had regressed and the kidneys were also barely palpable. A repeat ultrasound showed a significant reduction in the size of the kidneys. The child died after 2 wks of chemotherapy due to febrile neutropenia.

Clinically evident renal enlargement occurs in only 2$5 \%$ of leukemia patients. Renal failure consequent to such involvement occurs rarely. ${ }^{1}$ Also signs and symptoms of central nervous system involvement are seldom observed at initial presentation.

Although renal infiltration is relatively frequent in acute lymphoblastic leukemia, nephromegaly is unusual., ${ }^{2,3}$ Kidneys are the most frequent extramedullary site for leukemic cell infiltration. This infiltration is usually diffuse and bilateral with a predominant involvement of the renal cortex. Nodular and hypoechoeic lesions are seen with tumors like lymphoma. Renal infiltration is often associated with involvement of other extramedullary sites like central nervous system, testis and skin.

Mukta Mantan, Kamal Kumar Singhal and Gulshan Rai Sethi

Department of Pediatrics, Maulana Azad Medical College and associated Hospitals, University of Delhi, Delhi, India.

E-mail:muktamantan@hotmail.com [DOI-10.1007/s12098-010-0028-y]

\section{REFERENCES}

1. Gupta A, Malhotra HS, Kumar L, Sirwal IA, Sakhuja V, Chugh KS. Acute renal failure due to leukemic infiltration of kidneys. J Assoc Physicians India 1990; 38: 284-286.

3. Butani L, Paulson TE. Congenital acute myelogenous leukemia presenting as palpable renal masses in a neonate. $J$ Pediatr Hematol Oncol 2003; 25: 240-242.

3. Martins A, Cairoli H, Dominguez P, Martin S, Ortiz C, Postasznik J, Schenone N. Nephromegaly : an unusual presentation of acute lymphoblastic leukemia in an infant. Arch Argent Pediatr 2008; 106: 263-265. 